\title{
Analysis of Factors Affecting the Stickiness of Freight Forwarders Based on Customer Experience
}

\author{
Bin Yang, Jian Xue* \\ School of Economics and Management, Shanxi University of Science and Technology, Xi'an, China \\ Email: *xuejian2004@163.com
}

How to cite this paper: Yang, B., \& Xue, J. (2020). Analysis of Factors Affecting the Stickiness of Freight Forwarders Based on Customer Experience. American Journal of Industrial and Business Management, 10, 389-401.

https://doi.org/10.4236/ajibm.2020.102025

Received: January 20, 2020

Accepted: February 17, 2020

Published: February 20, 2020

Copyright $\odot 2020$ by author(s) and Scientific Research Publishing Inc. This work is licensed under the Creative Commons Attribution International License (CC BY 4.0).

http://creativecommons.org/licenses/by/4.0/

\begin{abstract}
Customer stickiness plays an important role in freight forwarding companies. From the perspective of customer experience, this paper collects market feedback information through a questionnaire survey, and uses factor analysis to analyze the relevant influencing factors of customer stickiness. The results show that the reform of freight forwarding companies must start from the main factors affecting customer stickiness, in order to meet the market demand to a certain extent, maintain a stable customer base, and increase customer stickiness. Therefore, bringing the main factors that affect the stickiness of customers into the development process of an enterprise is bound to gain more market competitiveness in its response to the increasingly changing international market.
\end{abstract}

\section{Keywords}

Customer Experience, Customer Stickiness, Freight Forwarding

\section{Introduction}

In the current situation, with the rapid development of Internet high technology, the development of digital innovation is an important opportunity for many traditional industries to face changes and improve their market competitiveness. The customer is the core subject of the enterprise, and it is true that the stickiness of the customer is bound to be one of the important concerns of the traditional international freight forwarders facing digital transformation and development. The main factors that affect customer stickiness are particularly important for understanding customer needs and improving the advantages and market position of freight forwarding companies. In terms of performance, starting from the point of customer experience, from the perspective of customer's beha- 
vior choice experience and psychological feeling experience, combined with customer satisfaction theory and customer stickiness theory, using factor analysis method to conduct empirical research and analysis to reach the impact on customers. The main factors of stickiness need to be considered from the perspective of behavioral stickiness and psychological stickiness. From the perspective of behavioral stickiness, it studies from the perspective of perception of the price, product, after-sales, convenience, and brand of the service of the freight forwarding company. From the perspective of psychological stickiness, it studies from the perspective of perceived service quality, that is, by perceptual reactivity, professionalism, and perception simulate the level of empathy and perceived trust. The research results confirm that customer stickiness is reflected in three aspects, sticky behavior habits, active recommendation stickiness, and sticky retention. Combining these three points and thinking on the basis of reality, the main factors that affect customer stickiness have practical significance for the transformation process of freight forwarders. The article can theoretically expand the value of the theory of customer stickiness in different industry fields. In fact, relying on the practical problems currently facing the freight forwarding industry field to provide professional method guidance, it has certain social value significance. The article structure starts from the following three parts: The first part is a brief overview of the concepts of customer stickiness, customer experience, and international freight forwarding through a literature review method. The second part is to select behavior and psychology as the main perspective of the customer experience, design a questionnaire that affects the customer stickiness of the freight forwarder and collect and organize the questionnaire, and use linear regression analysis to analyze the main factors that affect customer stickiness. The third part discusses the empirical results and proposes the main directions for maintaining customer stickiness and improving customer stickiness in the process of traditional enterprise transformation.

\section{Literature Review}

To explore the research dynamics of customer stickiness in different fields, objectively reflect the research capabilities of related fields based on the China Knowledge Base (CNKI) literature database source, using "customer stickiness/customer stickiness" as the search term, and retrieve the document date As of May 31, 2019, a total of 29 articles have been retrieved according to the time span. Through the measurement and visual analysis, the overall annual change trend is shown in Figure 1 .

It can be seen that the research on customer stickiness adhesion is currently on the rise. Using customer stickiness/adhesion as a keyword to search, it is found that the application is widely used in the Internet and business fields. The main reason for this situation is that with the rapid development of the Internet and the market economy, customer needs are becoming more and more obvious. The market competition of enterprises is not limited to pure price competition, and the combination of online and offline methods has also shown a variety of development, 
Customer sticky / sticky literature publishes annual trend chart

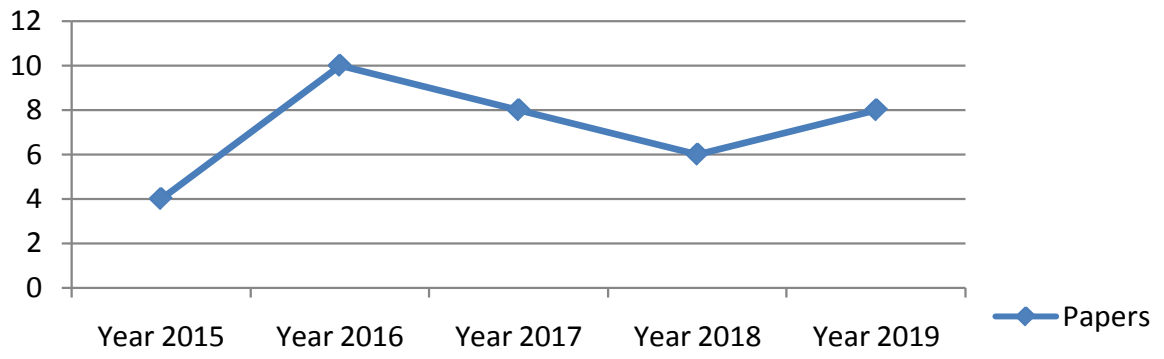

Figure 1. Annual trend of customer adhesive/adhesive literature publication.

so various industries strive to improve their own advantages to maintain the stability and longevity of corporate customers. It mainly starts with customers, and analyzes maintaining customers and corporate profits based on this as research objects.

\subsection{Customer Stickiness}

Nemzow M. (1999) most commonly defines stickiness as the process by which a first-time visitor converts to a customer and is able to repeat purchases. Paul (1999) defines stickiness as the ability to retain consumers and prompt them to return. Sheri Roson (2001) believes that customer stickiness is actually customer retention, customer loyalty, or customer repeats purchases. Ou, Wang, \& Xue, (2011) based on the psychological characteristics of consumers, it is an important factor affecting customer stickiness, such as customer attitude, overall satisfaction, customer preference, trust, commitment, willingness, and consumption habits, etc. Huang et al. (2015) summarized customer stickiness based on consumer loyalty, and proposed that if it can promote the improvement of consumer loyalty and maintain customer loyalty, enhancing customer stickiness can guide consumers to form long-term consumer behavior habits and improve the company's Brand competitiveness. In the context of combining the new economy and the Internet with a profound impact on consumer habits, traditional marketing methods must complete marketing transformation through sticky marketing, and that the value of the enterprise does not exist in the product or service. The customer experience is not only timely, but also a continuous satisfaction experience. In the Internet era, through the continuous development of technology, the communication between enterprises and customers gradually develops to "zero distance", and a full range of continuous interactive communication is carried out anytime, anywhere to maintain a close relationship between enterprises and customers. Further research believes that customer stickiness comes from customer behavior and psychology. Combining the customer's behavioral choices with the original psychological expectations, and then expanding the research perspective to the perspective of customer behavior, customer psychology could study the concept of customer stickiness. Hu (2006) believes that when customers feel better about the product experience, customers are more willing to ap- 
preciate the service and quality of the product, and make them feel happy, which will increase the probability of customers patronizing the company's products again. Therefore, it revealed relationship between scene impressions, perceived service quality, and behavioral intentions. Hu \& Jasper (2007) think that under normal circumstances, customers will leave an impression value on the product after experiencing the overall service. The level of the impression value affects the customer's satisfaction with the quality of the service. Kim \& Moon (2009) have conducted a series of studies on the level of perceived service quality. The emotional pleasure after customer choice will also promote their behavioral intentions. Therefore, high-quality services can bring emotional joy to customers, which in turn will affect customer initiative. It can promote their willingness to repurchase and greatly increases customer stickiness.

\subsection{Customer Experience and Customer Satisfaction}

Kotler \& Keller (2016), based on the perspective of cognitive theory, proposed that after consumer behavior, consumers give corresponding evaluations to their own demand expectations and the degree of service satisfaction. Kotler proposed that customer value is an evaluation based on customer expectations and the effects that customers can perceive. Enterprises not only need to manage from the value level, but also match the transmission and perception of value with customer expectations. F. Reichheld (1996) believes that the goal of a company should focus on customer loyalty rather than customer satisfaction itself, and make a brief analysis of the company's development direction. Deepen to achieve the improvement of customer loyalty, and put forward the "Net Promoter Score" NPS method (Net Promoter Score) as an indicator to measure the size of customer loyalty. Oliver (1999) pointed out that customer loyalty is based on customer satisfaction, and customer satisfaction in purchasing goods directly affects customer repurchase rate. If customer satisfaction is low, then repurchase Sexuality is bound to decrease. Therefore, the stickiness of customers also depends on customer satisfaction, and the importance of customer experience is true. $\mathrm{Hu} \mathrm{Yu}$ (2010) believes that customer satisfaction is a necessary condition for achieving customer loyalty. $\mathrm{Na}$ Wenzhong (2015) pointed out that from the perspective of customer experience, customer satisfaction must be achieved to a certain height, in order to promote customer repeat purchase behavior and increase customer stickiness. At the same time, the company gives customers the tangible and intangible benefits and costs through the sum of various benefits such as products, quality, prices, and services transmitted from the organization to customers. After being affected by advertisements or word-of-mouth, customers are prone to product and service expectations. By sensing product quality, they have a certain evaluation of the product or service. Therefore, on the premise of improving customer loyalty, through customer expectations, perceived value, perceived level of product or service quality, together, the level of customer satisfaction is formed. Of course, if customer complaints can be reduced to the minimum, it can also increase customer loyalty and increase customer stickiness. 


\subsection{Research on the Development of International Freight Forwarders}

The freight forwarder plays an intermediary role in international cargo transportation. It is responsible for arranging the agency transportation between the owner and the consignee, transporting the cargo to the designated place and obtaining corresponding compensation. L Wylie (1990) mainly introduce the scope of its business services mainly includes: First, air freight, the agency service can guarantee the fast and effective service requirements of the cargo, and at the same time also guarantee the safety of high-value cargo; second, the shipping agency service, as an intermediate role of the cargo transport carrier, has a non-vessel that has the measures of the transportation department. Under the premise of the carrier's qualifications, participate in the operation of non-vessel shipping business, and sign contracts with the cargo owner and international shipping companies respectively, and receive remuneration for intermediate agency services. The front-end of the output and the inward logistics of the logistics back-end deliver value-added services up to the last mile, providing the optimal service plan according to customer needs; fourth, the international multimodal transport service, for goods crossing at least two countries International transportation plans that provide at least two or more modes of combined transportation; fifth, contract logistics. Under the competitive pressure of value-added services, the function of contract logistics is mainly reflected in the warehousing of goods, and the service extends to the system in the supply chain of the enterprise, from material management to the delivery to the door. Docking, warehousing business involves special service needs such as labeling, sorting, packing, scanning, packaging, customs inspection, etc.; Sixth, integrated logistics, whose type of service mainly involves comprehensive services that meet the customer's personalized products, covering the whole from storage to the door. End-to-end logistics transportation needs. Relying on the Internet's increasingly innovative technology platform, customers can experience a diverse and personalized service experience. Forwarding companies (2018) will gradually develop services in the direction of "operating customers" and "operating logistics operation resources" under the premise of conforming to the market development model, combining logistics demand side and supply side demand to achieve steady business growth. Forwarder companies' digital representatives, such as Freightos and Flexport, have pushed their business models to digital platforms, bringing new and fast digital experiences to customers, and adding innovative momentum to the market. In addition, traditional freight forwarding companies such as Kuehne + Nagel, Maersk-Damco, etc. are also committed to digital innovation in marketing. Furthermore, MAERSK launched a portal website, https://www.maersk.com.cn/, to digitally upgrade the booking process, greatly reducing the time required for container booking, trying to cross the chain of intermediaries of freight forwarding companies, and directly participate in shipper transactions; in addition, Types of enterprises such as FedEx (including subsidiary TNT Express) and UPS rely on their own end-to-end IT systems to continuously expand in the logistics industry. 


\section{Analysis of Factors Affecting Customer Stickiness}

\subsection{Research Hypothesis Based on Customer Experience on Customer Stickiness Affecting Freight Forwarders}

As mentioned earlier, the most intuitive direction of customer physical examination is reflected in two levels, behavior choice experience and psychological feeling experience. The choice of behavior is to perceive the price, product, after-sale, convenience, brand of the freight forwarder from the perspective of perception service, and to perceive the response, professionalism, empathy, Reliability, which combines the two starting points of behavior and psychology, mainly affects customer stickiness in three aspects: sticky behavior habits, active recommendation stickiness, and sticky maintenance.

Therefore, this article makes assumptions based on two main directions:

Ha: Assume behavioral stickiness is positively correlated with customer stickiness.

Ha1: Price service is positively correlated with customer stickiness.

Ha2: Product service is positively related to customer stickiness.

Ha3: After-sales service is positively related to customer stickiness.

Ha4: Brand service is positively related to customer stickiness.

Ha5: Convenient service is positively related to customer stickiness.

$\mathrm{Hb}$ : Assume that psychological stickiness is positively related to customer stickiness.

$\mathrm{Hb} 1$ : Assume a positive correlation between perceived responsiveness and customer stickiness.

$\mathrm{Hb} 2$ : Assume a positive correlation between perceived professionalism and customer stickiness.

$\mathrm{Hb} 3$ : Assume that perception empathy is positively correlated with customer stickiness.

Hb4: Assume that perceived trust is positively correlated with customer stickiness.

\subsection{Survey Design}

The questionnaire design in this paper is based on the two main aspects of customer behavior choice and psychological feeling, and analyzes customer satisfaction with various elements of the company from the perspective of customer experience. Customer stickiness is the result-oriented. Repetitive purchases, that is, behavioral stickiness and active recommendation, are the main manifestations of customer stickiness and retention. Therefore, in terms of behavior choice, the main investigation is made on the price, product, after-sale, brand, and convenience of the enterprise, that is, an empirical investigation on the relevant influencing factors of behavior stickiness; in terms of psychological perception, it is mainly from the customer's conduct empirical investigations on responsiveness, professionalism, empathy, and trustworthiness, that is, empirical investiga- 
tions on relevant factors that mainly affect the psychological stickiness of customers. The questionnaire was designed based on the above related influencing factors. From 1 to 5 points, the score was evaluated from low to high, that is, 5 points were completely agreed, 4 points were more agreeable, 3 points were not understood, 2 points means the sub-representatives did not agree very much, and the 1point representative totally disagreed.

\subsection{Questionnaire Collection}

D Freight Forwarding Company is a foreign-funded enterprise engaged in traditional international freight forwarding business, hereinafter referred to as " $D$ Freight Forwarding Company". Founded in the early 19th century, it is one of the top 500 companies in the world. It has been committed to the steady development of the international logistics industry for many years. International logistics service products cover multi-style services such as sea transportation, air transportation, land transportation, contract storage, and multimodal transportation. With the continuous advancement and innovation of digitalization at this stage, the traditional international logistics services it covers also face a series of challenges in the development process of enterprises. This article uses D freight forwarding company as a sample, starting from the customer experience, respondents mainly come from business personnel and company logistics interface personnel of foreign trade companies with international logistics requirements. The questionnaires are divided between male and female participants. The working years are mainly between 3 and 12 years. Those with education level are mainly subjects with a bachelor degree or above, most of them are private companies. Most of the companies have a scale of 500 or more. They mainly design questionnaires on the factors affecting customer stickiness in order from the behavior and psychological aspects of customers, and issue 315 questionnaires. 315 were recovered and 315 were valid questionnaires. The recovery rate was $100 \%$. The sample is as below Table 1.

\subsection{Based on the Empirical Analysis of Customer Experience on the Influence of Freight Forwarding Customer Stickiness}

\subsubsection{Reliability Analysis}

Reliability is a measure of whether variables are repeated and consistent. Reliability tests can minimize the deviations and errors of research results as much as possible to ensure the authenticity of the data, thereby creating a prerequisite for the validity of the test. If the Cronbach $\alpha$ value is greater than 0.8 , the reliability of the data is high. If it is between 0.7 and 0.8 , the reliability is better.

According to the analysis of Table 2, if the reliability value is 0.93 , and the value is greater than 0.9 , the reliability of the data is very high. The analysis is performed by the " $\alpha$ coefficient of deleted items". The improvement further indicates that the reliability of the research data is high, and the survey results can be used for further analysis. 
Table 1. Statistics of the basic situation of the respondents.

\begin{tabular}{|c|c|c|c|c|}
\hline \multicolumn{5}{|c|}{ Basic Statistics of the Respondents } \\
\hline Item & Option & Frequency & Percentage (\%) & Cumulative percentage (\%) \\
\hline \multirow{2}{*}{ Gender } & Male & 159 & 50.48 & 50.48 \\
\hline & Female & 156 & 49.52 & 100 \\
\hline \multirow{4}{*}{ Working Years } & Under 3 years & 33 & 10.48 & 10.48 \\
\hline & 3 years - 12 years & 201 & 63.81 & 74.29 \\
\hline & 13 years - 27 years & 69 & 21.9 & 96.19 \\
\hline & Over 27 years & 12 & 3.81 & 100 \\
\hline \multirow{5}{*}{ Education Level } & $\begin{array}{l}\text { High school } \\
\text { and below }\end{array}$ & 6 & 1.9 & 1.9 \\
\hline & College & 78 & 24.76 & 26.67 \\
\hline & Undergraduate & 192 & 60.95 & 87.62 \\
\hline & Master & 36 & 11.43 & 99.05 \\
\hline & $\mathrm{PhD}$ & 3 & 0.95 & 100 \\
\hline \multirow{4}{*}{$\begin{array}{l}\text { The nature of the } \\
\text { company }\end{array}$} & Foreign Investment & 78 & 24.76 & 24.76 \\
\hline & Private & 159 & 50.48 & 75.24 \\
\hline & Joint Venture & 9 & 2.86 & 78.1 \\
\hline & $\begin{array}{l}\text { State-owned } \\
\text { Enterprise }\end{array}$ & 69 & 21.9 & 100 \\
\hline \multirow{4}{*}{ Company Size } & 50 people or less & 81 & 25.71 & 25.71 \\
\hline & 50 - 150 people & 48 & 15.24 & 40.95 \\
\hline & 150 - 500 people & 57 & 18.1 & 59.05 \\
\hline & 500 people or more & 129 & 40.95 & 100 \\
\hline Total & & 315 & 100 & 100 \\
\hline
\end{tabular}

Table 2. Reliability coefficient table of sample data.

\begin{tabular}{|c|c|c|c|c|}
\hline & \multicolumn{4}{|c|}{ Cronbach Reliability Analysis } \\
\hline & Items & $\begin{array}{l}\text { Total correlation } \\
\text { (CITC) }\end{array}$ & $\begin{array}{l}\text { Deleted } \alpha \\
\text { coefficient }\end{array}$ & $\begin{array}{l}\text { Cronbach } \alpha \\
\text { coefficient }\end{array}$ \\
\hline \multirow{5}{*}{$\begin{array}{l}\text { Behavioral } \\
\text { stickiness }\end{array}$} & Price service & 0.83 & 0.968 & \multirow{12}{*}{0.97} \\
\hline & Product service & 0.892 & 0.966 & \\
\hline & After sales service & 0.85 & 0.967 & \\
\hline & Brand Services & 0.823 & 0.968 & \\
\hline & Convenient service & 0.815 & 0.968 & \\
\hline \multirow{4}{*}{$\begin{array}{l}\text { Psychological } \\
\text { stickiness }\end{array}$} & Perceived responsiveness & 0.789 & 0.969 & \\
\hline & $\begin{array}{c}\text { Perceived } \\
\text { Professionalism }\end{array}$ & 0.88 & 0.967 & \\
\hline & Perceptual empathy & 0.902 & 0.966 & \\
\hline & Perceived reliability & 0.896 & 0.966 & \\
\hline \multirow{3}{*}{$\begin{array}{l}\text { Customer } \\
\text { stickiness }\end{array}$} & Sticky behavior & 0.909 & 0.966 & \\
\hline & $\begin{array}{l}\text { Active recommendation } \\
\text { stickiness }\end{array}$ & 0.871 & 0.967 & \\
\hline & Sticky retention & 0.751 & 0.972 & \\
\hline
\end{tabular}

Standardization Cronbach $\alpha$ coefficient: 0.973. 


\subsubsection{Validity Analysis}

Validity analysis is used to test the rationality of the design of quantitative data. This article uses SPSS19.0 software for analysis, and performs KMO sample measurement and Bartlett sphere test to measure the correlation between the data. KMO value if it exceeds 0.8 , the correlation coefficient between the variables and the higher the validity, if the value is less than 0.6 , then the validity poor.

Based on the results of Table 3 validity data analysis, the factor data analysis method was used to pass the KMO value, commonality, and variance interpretation rate values. In addition, the $\mathrm{KMO}$ value in the data is greater than 0.6 and the commonality value of all corresponding terms is higher than 0.4 . There is a clear correlation between the factors. It can be seen from the factor loading coefficient value that the correlation amount of the data has a good validity, which can be analyzed in the next step.

\subsubsection{Empirical Analysis}

This article sets the three manifestations of customer stickiness, that is, "behavioral stickiness", "active recommendation stickiness", and "repeated purchase stickiness" as independent variables. The main variables of "behavioral stickiness" and "psychological stickiness" are their customer stickiness. The expression method is analyzed by linear regression method, as shown in Table 4 below.

As shown in Table 4, the effects of behavioral choice and psychological feelings on customers' stickiness are analyzed to varying degrees. Choosing the main way of behavior performance, customers choose the price, product, after-sale, convenience, and then according to the level of psychological perception, feel the impact of their responsiveness, professionalism, empathy, and trust on customer stickiness. The principle of single factor analysis of variance is that when the independent variable value is less than 0.05 , it indicates that the independent variable has a significant effect on the dependent variable.

Based on the analysis of relevant factors with independent variable values less than 0.05 , from the perspective of behavioral stickiness of the dependent variable, on the level of behavioral stickiness, products and services have an important impact on behavioral stickiness. On the level of psychological stickiness, trust is important to behavioral stickiness. Impact; From the perspective of dependent variable active recommendation stickiness, at the level of behavioral stickiness, after-sales service has an important effect on active recommendation stickiness; at the level of psychological stickiness, feeling trust has an important effect on active recommendation stickiness; from the perspective of maintaining dependent variable stickiness, behavior At the level of stickiness, brand service has an important influence on the stickiness of active recommendation.

Based on the above assumptions, the following Table 5 empirical test results are obtained. 
Table 3. Validity analysis results.

\begin{tabular}{|c|c|c|}
\hline \multicolumn{3}{|c|}{ Validity Analysis Results } \\
\hline & Factor loading factor & \multirow{2}{*}{ Commonness } \\
\hline & Factor & \\
\hline Price service & 0.855 & 0.731 \\
\hline Product service & 0.912 & 0.832 \\
\hline After sales service & 0.881 & 0.775 \\
\hline Brand Services & 0.857 & 0.734 \\
\hline Convenient service & 0.848 & 0.719 \\
\hline Perceived responsiveness & 0.818 & 0.67 \\
\hline Perceived Professionalism & 0.904 & 0.817 \\
\hline Perceptual empathy & 0.922 & 0.851 \\
\hline Perceived reliability & 0.917 & 0.84 \\
\hline Sticky behavior & 0.926 & 0.857 \\
\hline Active recommendation stickiness & 0.893 & 0.797 \\
\hline Sticky retention & 0.785 & 0.616 \\
\hline Eigenvalue (before rotation) & 9.24 & - \\
\hline Variance interpretation\% (before rotation) & $77.001 \%$ & - \\
\hline $\begin{array}{l}\text { Cumulative variance interpretation rate } \% \\
\text { (before rotation) }\end{array}$ & $77.001 \%$ & - \\
\hline Eigenvalue (after rotation) & 9.24 & - \\
\hline Variance interpretation rate (after rotation) & $77.001 \%$ & - \\
\hline $\begin{array}{l}\text { Cumulative variance interpretation rate } \% \\
\text { (after rotation) }\end{array}$ & $77.001 \%$ & - \\
\hline KMO Value & 0.915 & - \\
\hline Bart sphericity & 1592.856 & - \\
\hline $\mathrm{df}$ & 66 & - \\
\hline $\mathrm{p}$ & 0 & - \\
\hline
\end{tabular}

\section{Research Conclusion}

Through questionnaire survey and brief analysis of the questionnaire, in the choice of behavior habits, we must pay attention to the price, after-sale, brand, service, and convenience of the product. According to empirical research, we should focus on product service and after-sale in the current situation. From the perspective of service and brand service, it plays a key role in enhancing the trust of customers and increasing the stickiness of customers. At present, freight forwarding companies are facing the environment of digital innovation. In the direction of product and service, they must integrate the Internet to achieve end-to-end systematic service extension. Starting from the online experience of customers, they can integrate online price inquiry, online ordering, and online tracking. Using the basic paperless operation mode to gradually innovate the traditional operation 
Table 4. Customers' stickiness of relevant factors.

(a)

\begin{tabular}{ccccccc}
\hline \multirow{2}{*}{ Model } & \multicolumn{2}{c}{ Unstandardized Coefficients } & $\begin{array}{c}\text { Standardized } \\
\text { Coefficients }\end{array}$ & T & Sig. \\
\cline { 2 - 3 } \cline { 6 - 6 } Constant & B & Std.Error & Beta & & 0.174 \\
\hline Price service & 0.078 & 0.057 & & 1.361 & 0.174 \\
Product service & 0.125 & 0.057 & 0.121 & 2.129 & 0.034 \\
After sales service & -0.160 & 0.066 & -0.140 & -2.405 & 0.017 \\
Brand Services & -0.077 & 0.051 & -0.074 & -1.510 & 0.132 \\
Convenient service & -0.124 & 0.042 & -0.122 & -2.969 & 0.003 \\
Perceived responsiveness & 0.146 & 0.068 & 0.133 & 2.148 & 0.032 \\
Perceived Professionalism & 0.156 & 0.081 & 0.139 & 1.915 & 0.056 \\
Perceptual empathy & 0.156 & 0.084 & 0.137 & 1.858 & 0.064 \\
Perceived reliability & 0.501 & 0.080 & 0.481 & 6.244 & 0.000 \\
\hline
\end{tabular}

Dependent variable: Sticky behavior.

(b)

\begin{tabular}{ccccccc}
\hline \multirow{2}{*}{ Model } & \multicolumn{2}{c}{$\begin{array}{c}\text { Unstandardized } \\
\text { Coefficients }\end{array}$} & $\begin{array}{c}\text { Standardized } \\
\text { Coefficients }\end{array}$ & \multirow{2}{*}{$\mathrm{T}$} & Sig. \\
\cline { 2 - 3 } \cline { 6 - 6 } & $\mathrm{B}$ & Std.Error & Beta & & 0.174 \\
\hline Constant & 0.256 & 0.100 & & 2.562 & 0.011 \\
Price service & 0.308 & 0.101 & 0.238 & 3.059 & 0.002 \\
Product service & -0.063 & 0.102 & -0.049 & -0.618 & 0.537 \\
After sales service & -0.465 & 0.117 & -0.316 & -3.986 & 0.000 \\
Brand Services & 0.036 & 0.090 & 0.027 & 0.397 & 0.692 \\
Convenient service & 0.383 & 0.073 & 0.294 & 5.218 & 0.000 \\
Perceived responsiveness & -0.026 & 0.119 & -0.018 & -0.215 & 0.830 \\
Perceived Professionalism & -0.243 & 0.143 & -0.169 & -1.705 & 0.089 \\
Perceptual empathy & 0.181 & 0.147 & 0.125 & 1.233 & 0.219 \\
Perceived reliability & 0.911 & 0.141 & 0.681 & 6.478 & 0.000 \\
\hline
\end{tabular}

Dependent variable: Active recommendation stickiness.

(c)

\begin{tabular}{ccccccc}
\hline \multirow{2}{*}{ Model } & \multicolumn{2}{c}{$\begin{array}{c}\text { Unstandardized } \\
\text { Coefficients }\end{array}$} & $\begin{array}{c}\text { Standardized } \\
\text { Coefficients }\end{array}$ & \multirow{2}{*}{$\mathrm{T}$} & Sig. \\
\cline { 2 - 4 } \cline { 6 - 6 } Constant & B & Std.Error & Beta & & 0.174 \\
\hline Price service & -0.093 & 0.138 & & & 7.933 & 0.000 \\
Product service & 0.075 & 0.149 & -0.036 & & -0.284 & 0.777 \\
After sales service & 0.255 & 0.161 & 0.068 & & 0.535 & 0.593 \\
Brand Services & -0.351 & 0.123 & -0.310 & -2.841 & 0.005 \\
Convenient service & 0.171 & 0.101 & 0.154 & 1.687 & 0.093 \\
Perceived responsiveness & -0.083 & 0.165 & -0.069 & -0.506 & 0.613 \\
Perceived Professionalism & 0.222 & 0.197 & 0.182 & 1.128 & 0.260 \\
Perceptual empathy & 0.055 & 0.203 & 0.045 & 0.272 & 0.785 \\
Perceived reliability & 0.105 & 0.194 & 0.092 & 0.541 & 0.589 \\
\hline
\end{tabular}

Dependent variable: Sticky retention. 
Table 5. Hypothesis test results.

\begin{tabular}{|c|c|c|}
\hline No. & Research hypothesis & Result \\
\hline $\mathrm{Ha}$ & $\begin{array}{l}\text { Assume behavioral stickiness is positively correlated with customer } \\
\text { stickiness }\end{array}$ & Approved \\
\hline Ha1 & Price service is positively correlated with customer stickiness & Approved \\
\hline $\mathrm{Ha} 2$ & Product service is positively related to customer stickiness & Approved \\
\hline На3 & After-sales service is positively related to customer stickiness & Approved \\
\hline $\mathrm{Ha} 4$ & Brand service is positively related to customer stickiness & Approved \\
\hline Ha5 & Convenient service is positively related to customer stickiness & Approved \\
\hline $\mathrm{Hb}$ & $\begin{array}{l}\text { Assume that psychological stickiness is positively related to customer } \\
\text { stickiness }\end{array}$ & Approved \\
\hline $\mathrm{Hb} 1$ & $\begin{array}{l}\text { Assume a positive correlation between perceived responsiveness and } \\
\text { customer stickiness }\end{array}$ & Approved \\
\hline $\mathrm{Hb} 2$ & $\begin{array}{l}\text { Assume a positive correlation between perceived professionalism and } \\
\text { customer stickiness }\end{array}$ & Approved \\
\hline $\mathrm{Hb} 3$ & $\begin{array}{l}\text { Assume that perception empathy is positively correlated with } \\
\text { customer stickiness }\end{array}$ & Approved \\
\hline $\mathrm{Hb} 4$ & $\begin{array}{l}\text { Assume that perceived trust is positively correlated with customer } \\
\text { stickiness }\end{array}$ & Approved \\
\hline
\end{tabular}

of manual phone and mail, and gradually optimize and improve the operation time; in the after-sales service of the product, under the premise of ensuring the reliability and safety of transportation, according to different Products and transportation national routes are designed to meet the needs of logistics solutions, professional services in cargo tracking, cargo insurance, cargo early warning; From the perspective of brand service, we must pay attention to improving the visibility and influence of the company in the industry, actively share the excellent cases of the company on the platform, and make real-time publicity on the development of the industry and market changes in video or text, which could improve customer stickiness to a certain extent as well.

\section{Insufficient Research}

This article mainly investigates the logistics personnel of foreign trade companies with a high frequency of use, and their working experience is mainly in the age group of 3 to 12 years. This segment of the population happens is the main body to closely connect with the freight forwarder, but it cannot be denied that their working experiences also have certain limitations on the evaluation of freight forwarding. Freight forwarding companies, as one of the modules in the logistics chain of the supply chain, have a large cognitive space in terms of breadth and depth. The scope of the questionnaire survey is still insufficiently representative. Analysis has an impact.

\section{Conflicts of Interest}

The authors declare no conflicts of interest regarding the publication of this paper. 


\section{References}

Hu, H. (2006). Social Cues in the Store Environment and Their Impact on Store Image. International Journal of Retail \& Distribution Management, 34, 25-48. https://doi.org/10.1108/09590550610642800

Hu, H., \& Jasper, C. R. (2007). A Cross-Cultural Examination of the Effects of Social Perception Styles on Store Image Formation. Journal of Business Research, 60, 222-230. https://doi.org/10.1016/j.jbusres.2006.09.027

Hu, Y. (2010). Cross Customer Satisfaction to Loyalty. Journal of Educational Institute of Jilin Province, No. 9, 58-59.

Huang, L., Jia, L., \& Song, J. (2015). Antecedents of User Stickiness and Loyalty and Their Effects on Users' Group-Buying Repurchase Intention. In Twenty First Americas Conference on Information Systems (pp. 1-17). Puerto Rico: AIS.

Kim, W. G., \& Moon, Y. J. (2009). Customers' Cognitive, Emotional and Actionable Response to the Services Cape: A Test of the Moderating Effect of the Restaurant Type. International Journal of Hospitality Management, 28, 133-156. https://doi.org/10.1016/j.ijhm.2008.06.010

Kotler, P., \& Keller, K. L. (2016). Marketing Management (14th edition). Shanghai: Shanghai People's Publishing House.

Na, W. Z. (2015). Customer Value Realization and Customer Loyalty Promotion Strategy. Journal of Commercial Economics, 25, 73-74.

Nemzow, M. (1999). Ecommerce Stickiness for User Retention. Journal of Internet Banking and Commerce, 4, 34-39.

Oliver, R. L. (1999). Whence Consumer Loyalty? Journal of Marketing, 63, 33-44. https://doi.org/10.2307/1252099

Ou, X., Wang, Q., \& Xue, J. (2011). Review of Consumer Stickiness Research from Influence Factor Perspective. In International Conference on Advances in Education and Management (pp. 219-224). Berlin: Springer.

https://doi.org/10.1007/978-3-642-23062-2_33

Paul B. Yahoo (1999). Getting Sticky with It. Wired News, 1999-03-22.

Reichheld, F. (1996). Learning from Customer Defections. Harvard Business Review, 74, 56-70.

Sheri, R. (2001). Sticky Website Is Key to Success. Communication World, 18, 36.

Wylie, L. (1990). ERP: A Vision of the Next-Generation MRP II. Research Report. 